\title{
Echo-Tracking Is a Novel Technology to Assess Structural and Functional Properties of Carotid Arteries (Review)
}

DOI: $10.17691 / \mathrm{stm} 2016.8 .2 .16$

Received September 28, 2015

E.A. Melnikova, Tutor, Therapy Department;

I.V. Avdeeva, MD, PhD, Associate Professor, Therapy Department;

V.E. Oleynikov, MD, DSc, Professor, Head of Therapy Department

Penza State University, 40 Krasnaya St., Penza, 440026, Russian Federation

The problem of searching and large-scale implementation of early diagnostic techniques of cardiovascular diseases at the stage of preclinical failure is still relevant. Novel methods for vessel stiffness assessment to stratify cardiovascular risk and determine the aim of treatment intervention are certain to provoke interest.

The review considers the modern aspects of local stiffness of an arterial wall, and presents comparative data on ultrasound capabilities when using a standard B-mode and a new technique: echo-tracking. Software echo-tracking applications (QIMT and QAS) are described. We analyzed the parameters characterizing local rigidity. Obtaining measurement data minimally dependent on researcher's attitude was found to be an evident advantage of echo-tracking. The paper gives the guide values of a norm for the parameters under study in different age subgroups, and demonstrates diagnostic and prognostic value of the obtained parameters and their dynamics during the drug therapy.

Key words: echo-tracking; arterial stiffness; carotid arteries; atherosclerosis.

Despite certain advances in medical science, incidence, disability and mortality from cardiovascular pathology are still high worldwide. There is fragrant necessity to search and implement widely early diagnostic techniques for cardiovascular diseases as early as at the stage of preclinical involvement, and develop a common algorithm of preventive examination to stratify risk groups and develop their further management [1-3]. The alteration of aorta, carotid and femoral arteries is a significant marker of cardiovascular events. Elastic arteries provide both: blood carrying to periphery, and also damping of pressure wave forming due to cardiac output [4-8]. The diagnostics of arterial wall properties altered is of great importance for medical practice. Most patients with arterial hypertension $(\mathrm{AH})$, who are under care of a primary care physician, are those suffering from moderately expressed carotid atherosclerosis (carotid artery narrowing is under $50 \%$ [9]. According to different authors, combined atherosclerotic involvement of coronary, carotid and peripheral arteries occurs in $30-65 \%$ cases [7, 1012]. Therefore, the determination of elastic properties of carotid arteries is of special concern, and used in numerous studies, as well as recommended to be used by general practitioners $[1,2,4]$.

\section{Radiofrequency analysis peculiarities of carotid arteries}

Currently, there are a lot of techniques, which enable to estimate the arterial bed state. Ultrasound investigation (US) of arteries of different localization is highly informative and the most common diagnostic procedure. Routine US enables to determine rather quickly and invasively the atherosclerosis of surface arteries including carotid ones. The increase in carotid intima-media thickness (CIMT) and atheroma detection in carotid arteries are known to increase significantly cardiovascular risk, and require patient's management and combination therapy [13]. In accordance with Mannheim protocol, carotid arteries US for CIMT measurement is performed $1.5-2.0 \mathrm{~cm}$ proximal of the bifurcation of common carotid artery, the upper normal level being determined as $0.9 \mathrm{~mm}$ [14-18]. However, there are evidences that this index value $(0.9 \mathrm{~mm})$ cannot be considered as a norm for patients of different ages, sex and nationalities [19, 20]. Currently, there are imaging techniques, which enable to measure CIMT to greater accuracy.

Among these techniques there is a relatively new echo-tracking program available in US scanners

For contacts: Valentin E. Oleynikov, e-mail: v.oleynikof@gmail.com 
MyLab25/30, MyLab50, MyLab60/70/90/XVG (Esaote, Italy), as well as in some Aloka modifications (Hitachi, Japan). The program is based on standard B-mode with the integrated radiofrequency "filling" of a signal, it consisting in echo-contrast boundary monitoring that enables to track the altered artery diameter during different cardiac cycle phases [7, 19, 20]. Radiofrequency analysis minimizes data loss compared to the systems using video image analysis.

The technique was first mentioned in foreign literature

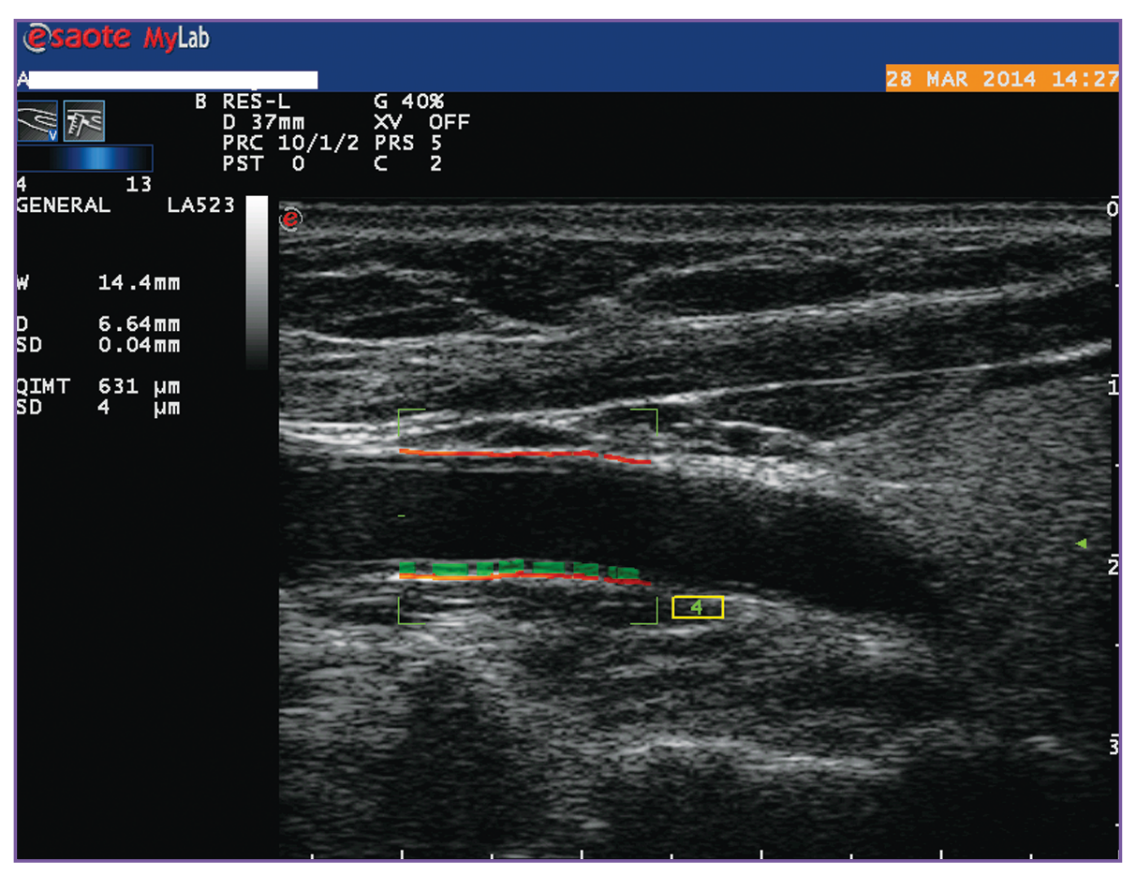

Figure 1. The measurement of carotid intima-media thickness by real-time echo-tracking (our study findings); $D$ is artery diameter; $S D$ is standard deviation; QIMT is Quality Intima-Media Thickness

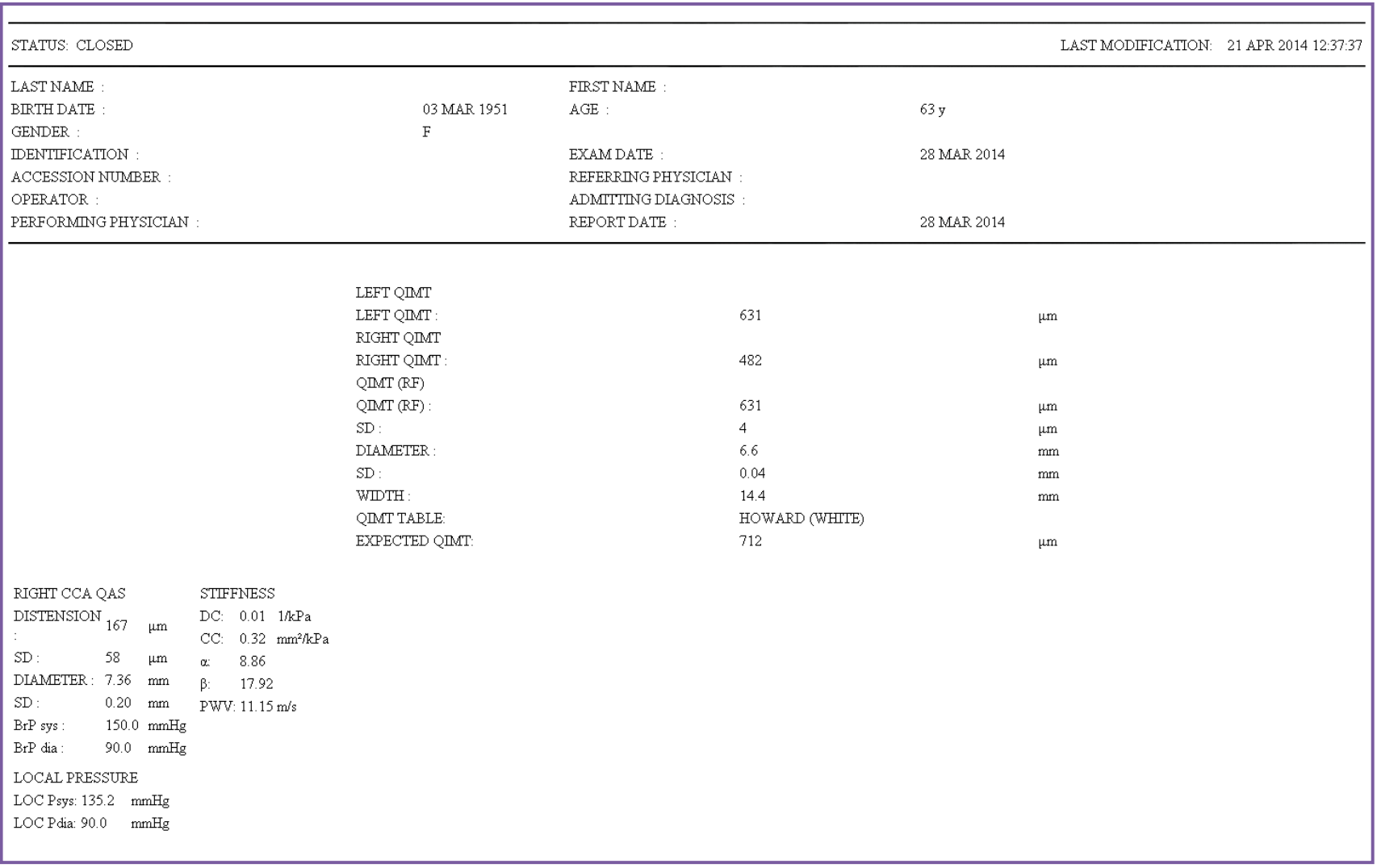

Figure 2. Image of measurement results of carotid intima-media thickness and local rigidity parameters (our study findings) 
in 2001 [21]. In Russian Federation echo-tracking technology has become available since 2011 in US scanners MyLab (Esaote).

Currently, it is possible to use two software applications for echo-tracking: QIMT (Quality IntimaMedia Thickness) and QAS (Quality Arterial Stiffness). Since all measurements are real-time, their further processing is unnecessary that minimizes an impact of a medical researcher on the findings. The accuracy of the equipment units based on radiofrequency usage is 6-10 times higher compared to those based on video image analysis. The measurement of absolute distance of standard deviation (SD) for devices based on video image analysis was found to be 54-60 $\mu \mathrm{m}$; the same parameter for echo-tracking varies within 9-25 $\mu \mathrm{m}$ [22-26]. Echo-tracking software provides measurement findings minimally dependent on researcher's attitude, which in routine practice can be corrected by a sonologist (e.g., an angle under study, scanning depth, image magnification, etc.) (Figure 1).

CIMT calculations performed by the first application of echo-tracking function (QIMT program) is fully automatic, a researcher just mounts a sensor on an artery view region, and starts up a program. A frame of "measurement gates" appears on a display, and automatically outlines a vessel wall to automatically measure its thickness. To assess the validity of program operation and control the accuracy of measurements there is a number of control characteristics, such as SD: the results are considered correct if $S D$ is in the range of 5-15 $\mu \mathrm{m}$. Resolution of the technique reaches $10 \mu \mathrm{m}$, technical errors being less than $17 \mu \mathrm{m}$ in vitro and $30 \mu \mathrm{m}$ in vivo [26] (Figure 2).

US scanners with echo-tracking function have integrated Howard table showing CIMT dependence on age and sex, and are based on the results of a prospective epidemiological ARIC Study, which enrolled about 15,792 healthy subjects of different age groups $[27,28]$.

The second echo-tracking application - QAS program - enables to estimate local rigidity of vessels $[29,30]$. The operation principle is to determine the amplitude of vessel wall movement during a pulse wave, and record the alterations of inside and outside diameters, as well as vessel volume in systole and diastole.

\section{Local characteristics of rigidity assessed by echo-tracking}

Calculation formulas integrated in the unit enable to assess some local characteristics of rigidity of the arteries under study: artery distensibility, pulse wave velocity, rigidity index, etc.

Let us take a detailed look at these parameters. Artery distensibility during the left ventricular systole is known to depend on vessel wall elastic properties and local pressure value in a vessel. The relationship can be expressed as $C=\Delta V / \Delta P$, where $C$ is compliance; $\Delta V$ is systolic and diastolic changes of vessel segment volume, $\Delta P$ is pulse pressure $[7,31-36]$. Considering that arterial wall compliance does not depend on

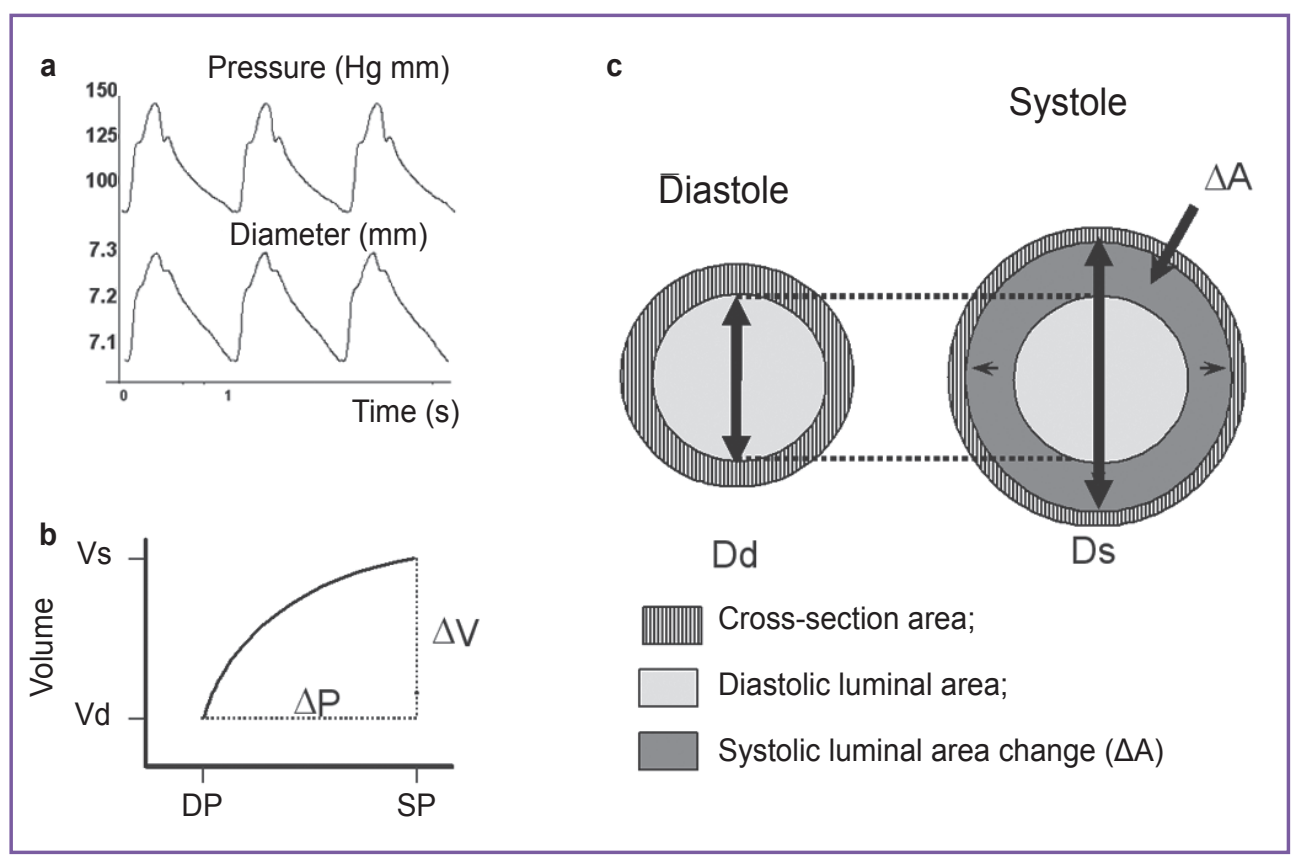

Figure 3. Local arterial distensibility: (a) simultaneous recording of changes in pressure amplitude and diameter; (b) pressure-volume curve; (c) schematic diagram of cross-section lumen changes 
pressure level in a vessel, we can devise a formula of compliance coefficient $(C C)$ of a vessel wall:

$$
C C=\Delta A / \Delta p=[3.14 \cdot D d(D s-D d) / 2] / \Delta p\left(\mathrm{~mm}^{2} / \mathrm{kPa}\right),
$$

where $\Delta A$ is vessel cross-section variation in systole; $\Delta p$ is pulse pressure; $D s$ is artery diameter in systole; $D d$ is artery diameter in diastole (Figure 3).

Arterial wall compliance characterizes the vessel capability to transform a pulsatile flow into a continuous flow.

Arterial distensibility, i.e. the wall capability to resist blood pressure wave, is estimated by a cross-section distensibility coefficient $(D C)$ formula:

$$
D C=\frac{\Delta A}{A \cdot \Delta p}=2[(D s-D d) / D d] \Delta p(1 / \mathrm{kPa}) .
$$

Pulse wave velocity (PWV) is a common parameter characterizing the arterial bed condition. Its value increases proportionally with vessel wall rigidity. Echotracking technology enables to calculate local PWV in any arterial system area that can be visualized. The calculation is automatic according to the following formula:

$$
P W V=\frac{1}{\sqrt{\rho \cdot D C}}=\sqrt{\frac{D^{2} \cdot \Delta p}{\rho\left(2 \cdot D \cdot \Delta D+\Delta D^{2}\right)}},
$$

where $D$ is diastolic diameter; $\Delta D$ is diameter alteration in systole; $D C$ is distensibility coefficient; $\Delta p$ is local pulse pressure; $\rho$ is blood density.

There is one more index of arterial condition, which echo-tracking can calculate. It is stiffness index $\beta$. It reflects the vessel wall capability to resist deformities: the higher $\beta$ value, the higher the wall rigidity:

$$
\beta=\int(S P / D P) D / \Delta D \text {. }
$$

where $S P$ is systolic, $D P$ is diastolic pressure in the carotid artery.

Index a characterizes the vessel cross-section variation in pulse wave:

$$
\alpha=A d \cdot \int(S P / D P) /(A s-A d),
$$

where $A s$ and $A d$ is the vessel cross-section area in systole and diastole, respectively.

Augmentation index (Aix) is a parameter dependent on pressure value in local area of bloodstream. It shows the difference between the first and the second systolic peaks in a vessel; its level is partially due to return time and reflected wave amplitude:

$$
\text { Aix }=[A P /(S P-D P)] 100 \% \text {, }
$$

where $A P$ is augmentation pressure, $S P$ and $D P$ is local systolic/diastolic pressure [38-41].

\section{Local rigidity and CIMT values according to current research data}

Relative novelty of the technique is explained by the absence of tight standards for parameters obtained by echo-tracking. However, increasingly more researchers give preference to the local rigidity study of carotid arteries using this program that is due to both: the simplicity and the accuracy of the technique, and also a close anatomical position of carotid arteries to aorta, and their surface position and accessibility [42-46].

In 2008 there were published the results of carotid arteries elasticity properties studied by echo-tracking in Chinese population [47]. The study included 4,812 healthy subjects $(1,971$ - men, 2,841 - women) aged from 5 to 80 years (mean age is $33.7 \pm 10.8$ years). All subjects enrolled in the study were non-smokers, had no previous complaints of cardiovascular events, their lipid metabolism and blood pressure indices conformed with norms, common CIMT was $\leqslant 0.1 \mathrm{~cm}$. Rigidity index $\beta$ at the age of 30-39 years was found to be $6.55 \pm 2.0$, and then increased proportionally to age, in a group of people over 60 it being $10.71 \pm 3.9$. Local PWV in carotid arteries in subjects of similar age groups was $5.42 \pm 2.0$ and $6.99 \pm 1.4 \mathrm{~m} / \mathrm{s}$. CC in people under 30 years had maximal values: $1.18 \pm 0.4$, and in healthy subjects over 60 years it decreased up to $0.73 \pm 0.3$. Considering the scope of research, the findings enable to consider conventionally these indices in age subgroups to be guide values for this method. The research results showed such parameters as rigidity index $\beta$ and local PWV to increase with age, while CC, on the contrary, tended to decrease. It can be explained by chronological aging of a vessel wall. The specified parameters demonstrated high reliable correlation in all age subgroups, while local augmentation index Aix showed weak correlation with other indices, and, respectively, low prognostic value.

Further investigation in Chinese population showed index $\beta$ and local PWV to increase significantly in smokers compared to non-smokers (regardless the presence of other risk factors of cardiovascular complications), while Aix index appeared to be significantly lower than that in smokers with $A H$, dislipidemy and hyperglycemia [48]. Moreover, in three mentioned groups systolic and diastolic diameters of carotid arteries differed significantly, while the subjects with several risk factors turned out to have significantly higher systolic and diastolic pressure in common carotid artery.

A team of Italian researchers [49] published the findings of their pilot study aimed at searching and evaluating differences in rigidity indices of carotid arteries measured by echo-tracking, among healthy subjects and human immunodeficiency virus (HIV) patients with no cardiovascular events. They examined 54 healthy subjects, and 54 HIV patients, the groups being compatible in age, sex and other anthropometric parameters. It should be noted that the differences between the groups in local rigidity and CIMT did not reach their statistical significance. CC values only appeared to be reliably lower in HIV patients. Mean age of controls was 48 years, $\beta$ index was $6.61(5.45-8.90)$, 
CC was 0.95 (0.78-1.23), local Aix was 15.40 (9.15$23.20) \%$, carotid PWV was $5.8(5.32-6.40) \mathrm{m} / \mathrm{s}$, common CIMT was $690(540-800) \mu \mathrm{m}$. Local rigidity indices in both groups showed positive significant correlation with age, and negative significant correlation of age with $C C$ due to reduced carotid arterial compliance at ageing, which are consistent with the results obtained by other researchers. In addition, arterial compliance reduction did not depend on antiretroviral therapy regimen $[49,50]$.

The data on carotid arteries obtained by echotracking in patients with retarded coronary flow is of particular interest [51]. The research included the patients with normal $(n=50)$ and pathological $(n=50)$ coronoangiography findings. Index $\beta$ and local PWV appeared to be significantly higher when coronary flow velocity decreased that can indirectly indicate a microvascular event, endothelial dysfunction, atherosclerosis of small and epicardial arteries. The findings reliably correlated with the level of high sensitivity C-reactive protein.

Predictive role of aortal rigidity in the prognosis of general and cardiovascular mortality was proved in patients with $\mathrm{AH}$ [52-55], diabetes mellitus [56, 57], terminal renal failure, as well as in elderly people [52, 55]. Most studies assessed rigidity by carotid-femoral PWV as an index indicating the state of elastic arteries. Arterial involvement of various localization is known to differ in AH patients, and with age [58-60]. So, peripheral arteries, primarily, muscular ones, such as brachial, radial, and femoral, to a lesser degree, are subjects to alterations due to the above described factors. Prognostic value of carotid rigidity was determined in cardiovascular complications developing in patients with terminal renal failure and after renal transplantation [6168]. CIMT of common carotid artery is a proved predictor of cardiovascular events in different patients' groups [7, 26, 30, 69-74].

Three groups of patients underwent a comparative examination in order to determine the relationships between arterial fluid parameters locally measured in carotid artery (echo-tracking), and aortal fluid estimated by carotid and femoral PWV [75]. Among 463 subjects under study there were 94 healthy subjects, 243 patients with essential $\mathrm{AH}$, and 126 patients with $\mathrm{AH}$ combined with type 2 diabetes mellitus. The distensibility of carotid arteries were found to be significantly lower, and local $\mathrm{PWV}$ was higher in $\mathrm{AH}$ patients (isolated $\mathrm{AH}$, and $\mathrm{AH}$ in combination with type 2 diabetes mellitus) compared to normotensive subjects. The correlation analysis of aortal and carotid PWV parameters showed positive reliable findings in a group in general $(r=0.34 ; p<0.001)$, and in each subgroup, in particular. The strongest correlations between the indices of two type rigidity were found in healthy subjects. These findings confirm the results of other studies on a predictive role of carotid fluid determination in groups of patients without concomitant cardiovascular pathology [75-83].
Beaussier et al. [84, 85] showed using echo-tracking that if $\mathrm{AH}$ patients have atherosclerotic plaques in carotid arteries, the arterial wall becomes less elastic in the place of plaque localization than that in superjacent areas resulting in carotid artery extension inside the atherosclerotic involvement. It can lead to "a mechanical fatigue" and provoke its rupture. The assessment of plaque structure using magnetic resonance tomography in addition to echo-tracking enabled to conclude that the altered shift of carotid artery wall depends on both: the plaque presence, and also its structure that enables to distinguish high-risk plaques [85-90].

The method is certain to be unable to replace routine US of carotid arteries [37, 91-94], in particular, when determining surgical indications. However, even now it enables to estimate the efficiency of drug therapy provided. According to Russian researchers, against the background of 24-week therapy with angiotensin receptor blockers as a part of a combined therapy in patients with coronary heart disease and $\mathrm{AH}$, echotracking showed significant CIMT decrease, as well as the improvement of most characteristics of local rigidity, in particular, $S P$ and $D P$, index $\beta, C C$, carotid artery PWV [95].

Further investigations are certain to be required to determine all the capabilities of echo-tracking in arterial wall involvement diagnosis. However, it is obvious even now that the technique due to its peculiarities is very promising for the determination of a long-term prognosis and the efficacy assessment of drug therapy provided [96-99].

Study Funding. The study was not funded by any sources.

Conflicts of Interest. The authors have no conflicts of interest related to the present study.

\section{References}

1. National guidelines on cardiovascular prevention. Kardiovaskulyarnaya terapiya i profilaktika 2011; 10(6): Suppl 2.

2. Natsional'nye klinicheskie rekomendatsii [National clinical guidelines]. Pod red. Oganova R.G. [Oganov R.G. (editor)]. Moscow: Silitseya-Poligraf; 2010; 592 p.

3. Diagnostics and correction of lipid metabolism disorders for prevention and treatment of atherosclerosis. Russian recommendation, version V. Ateroskleroz i dislipidemii 2012; 4(9): 5-45.

4. Van Bortel L.M., Laurent S., Boutouyrie P., Chowienczyk P., Cruickshank J.K., De Backer T., Filipovsky J., Huybrechts S., Mattace-Raso F.U., Protogerou A.D., Schillaci G., Segers P., Vermeersch S., Weber T.; Artery Society; European Society of Hypertension Working Group on Vascular Structure and Function; European Network for Noninvasive Investigation of Large Arteries. Expert consensus document on the measurement of aortic stiffness in daily practice using carotid-femoral pulse wave velocity. J Hypertens 2012; 30(3): 445-448, http://dx.doi.org/10.1097/ HJH.0b013e32834fa8b0. 
5. Milyagin V.A., Komissarov V.B. Modern methods of evaluation of vascular stiffness. Arterial'naya gipertenziya 2010; 2(16): 134-143.

6. Kobalava Zh.D., Kotovskaya Yu.V., Moiseev V.S. Arterial'naya gipertoniya. Klyuchi $k$ diagnostike $i$ lecheniyu [Arterial hypertension. The keys to diagnosis and treatment]. Moscow: GEOTAR-Media 2009; 864 p.

7. Laurent S., Cockcroft J., Van Bortel L., Boutouyrie P., Giannattasio C., Hayoz D., Pannier B., Vlachopoulos C., Wilkinson I., Struijker-Boudier H. Expert consensus document on arterial stiffness: methodological issues and clinical applications. Eur Heart J 2006; 27(21): 2588-2605, http:// dx.doi.org/10.1093/eurheartj/ehl254.

8. Oleynikov V.E., Matrosova I.B., Gusakovskaya L.I., Sergatskaya N.V. Role of the determination of aortic pressure and rigidity aortic in patients with cardiovascular diseases. Terapevticheskiy arkhiv 2014; 86(4): 91-95.

9. Krevchik V.D., Oleynikov V.E., Matrosova I.B., Sergatskaya N.V., Gusakovskaya L.I. Hemodynamic effects of direct and reflected pulse waves's interaction. Meditsinskaya fizika 2012; 2: 91-96.

10. Pozdnyakov Yu.M., Volkov V.S. Ambulatornoe lechenie osnovnykh zabolevaniy vnutrennikh organov [Outpatient treatment of major diseases of internal organs]. Moscow; 2008; $322 \mathrm{p}$.

11. Aronov D.M., Lupanov V.P. Some aspects of the pathogenesis of atherosclerosis. Ateroskleroz $i$ dislipidemii 2011; 1: 46-58.

12. Gurevich V.S. Modern views on the pathogenesis of atherosclerosis. Bolezni serdtsa i sosudov 2006; 4: 4-7.

13. Oikawa M., Ota H., Takaya N., Miller Z., Hatsukami T.S., Yuan C. Carotid magnetic resonance imaging. A window to study atherosclerosis and identify high-risk plaques. Circ J 2009; 73(10): 1765-1773, http://dx.doi.org/10.1253/circj.cj09-0617.

14. Celermajer D.S., Sorensen K.E., Gooch V.M., Spiegelhalter D.J., Miller O.I., Sullivan I.D., Lloyd J.K., Deanfield J.E. Non-invasive detection of endothelial dysfunction in children and adults at risk of atherosclerosis. Lancet 1992; 340(8828): 1111-1115, http://dx.doi. org/10.1016/0140-6736(92)93147-f.

15. Nedogoda S.V., Chalyabi T.A. Arterial stiffness and pulse wave velocity: new risk factors for cardiovascular disease and targets for pharmacotherapy. Bolezni serdtsa $i$ sosudov 2006; 4: 21-32.

16. Reneman R.S., Meinders J.M., Hoeks A.P.G. Noninvasive ultrasound in arterial wall dynamics in humans: what have we learned and what remans to be solved. Eur Heart J 2005; 26(10): 960-966, http://dx.doi.org/10.1093/eurheartj/ ehi177.

17. Lelyuk V.G., Lelyuk S.E. Osnovy klinicheskoy interpretatsii dannykh ul'trazvukovykh angiologicheskikh issledovaniy [Basics of clinical data interpretation at ultrasound angiological research]. Moscow; 2005.

18. Lelyuk V.G., Lelyuk S.E. Printsipy ul'trazvukovoy diagnostiki porazheniy sosudistoy sistemy [Principles of diagnostic ultrasound of lesions of the vascular system]. Moscow; 2002.

19. Laurent S., Boutouyrie P., Lacolley P. Structural and genetic bases of arterial stiffness. Hypertension 2005; 45(6): 1050-1055, http://dx.doi.org/10.1161/01. HYP.0000164580.39991.3d.

20. Mattace-Raso F.U., van der Cammen T.J., Hofman A., van Popele N.M., Bos M.L., Schalekamp M.A., Asmar R., Reneman R.S., Hoeks A.P., Breteler M.M., Witteman J.C. Arterial stiffness and risk of coronary heart disease and stroke: the Rotterdam Study. Circulation 2006; 113(5): 657-663, http:// dx.doi.org/10.1161/CIRCULATIONAHA.105.555235.

21. Van Bortel L.M., Balkestein E.J., van der HeijdenSpek J.J., Vanmolkot F.H., Staessen J.A., Kragten J.A., Vredeveld J.W., Safar M.E., Struijker Boudier H.A., Hoeks A.P. Non-invasive assessment of local arterial pulse pressure: comparison of applanation tonometry and echotracking. J Hypertens 2001; 19(6): 1037-1044, http://dx.doi. org/10.1097/00004872-200106000-00007.

22. Rogoza A.N., Balakhonova T.V., Chikhladze N.M., Pogorelova O.A., Moiseeva N.M., Sivakova O.A. Sovremennye metody otsenki sostoyaniya sosudov u bol'nykh arterial'noy gipertoniey [Modern methods of evaluation of the state of blood vessels in patients with arterial hypertension]. Moscow; 2008.

23. Eriksson A., Greiff E., Loupas T., Persson M., Pesque P. Arterial pulse wave velocity with tissue Doppler imaging. Ultrasound Med Biol 2002; 28(5): 571-580, http://dx.doi. org/10.1016/s0301-5629(02)00495-7.

24. Carerj S., Nipote C., Zimbalatti C., Zito C., Sutera Sardo L., Dattilo G., Oreto G., Arrigo F. 388 Normal vascular aging evaluated by a new tool: e-tracking. Eur $J$ Echocardiogr 2006; 7(Suppl 1): S49, http://dx.doi.org/10.1016/s15252167(06)60178-9.

25. Harada A., Okada T., Niki K., Chang D., Sugawara M. On-line non-invasive one-point measurements of pulse wave velocity. Heart Vessels 2002; 17(2): 61-68, http://dx.doi. org/10.1007/s003800200045.

26. Touboul P.-J., Hennerici M.G., Meairs S., Adams H., Amarenco P., Bornstein N., Csiba L., Desvarieux M., Ebrahim S., Fatar M., Hernandez Hernandez R., Jaff M., Kownator S., Prati P., Rundek T., Sitzer M., Schminke U., Tardif J.-C., Taylor A., Vicaut E., Woo K.S., Zannad F., Zureik M. Mannheim carotid intima-media thickness consensus (2004-2006). Cerebrovasc Dis 2007; 23: 75-80, http://dx.doi. org/10.1159/000097034.

27. Riley W.A., Evans G.W., Sharrett A.R., Burke G.L., Barnes R.W. Variation of common carotid artery elasticity with intimal-medial thickness: the ARIC Study. Ultrasound Med Biol 1997; 23(2): 157-164, http://dx.doi.org/10.1016/s03015629(96)00211-6.

28. Yang E.Y., Chambless L., Sharrett A.R., Virani S.S., Liu X., Tang Z., Boerwinkle E., Ballantyne C.M., Nambi V. Carotid arterial wall characteristics are associated with incident ischemic stroke but not coronary heart disease in the Atherosclerosis Risk in Communities (ARIC) Study. Stroke 2012; 43(1): 103-108, http://dx.doi.org/10.1161/ STROKEAHA.111.626200.

29. Sidorenko G.I., Frolov A.V., Vorob'ev A.P., Mel'nikova O.P., Zolotukhina S.F. Skorost' pul'sovoy volny kak klyuch k otsenke disfunktsii endoteliya. V kn.: Diagnostika i lechenie narusheniy regulyatsii serdechno-sosudistoy sistemy [Pulse wave velocity as a key to the assessment of endothelial dysfunction. In: Diagnosis and treatment of disorders of the cardiovascular system regulation]. Moscow; 2008; p. 99-106.

30. Orlova Ya.A., Ageev F.T. Arterial stiffness as an integral indicator of cardiovascular risk: physiology, methods of assessment and medical correction. Serdtse 2006; 5(2): 65-69.

31. Lunder M., Janic M., Kejzar N., Sabovic M. Associations among different functional and structural arterial wall properties and their relations to traditional cardiovascular 
risk factors in healthy subjects: a cross-sectional study. BMC Cardiovasc Disord 2012; 12: 29, http://dx.doi. org/10.1186/1471-2261-12-29.

32. Bennett M.J., McLaughlin S., Anderson T., McDicken W.N. Error analysis of ultrasonic tissue Doppler velocity estimation techniques for quantification of velocity and strain. Ultrasound Med Biol 2007; 33(1): 74-81, http://dx.doi. org/10.1016/j.ultrasmedbio.2006.07.040.

33. Meinders J.M., Brands P.J., Willigers J.M., Kornet L., Hoeks A.P. Assessment of the spatial homogeneity of artery dimension parameters with high frame rate 2-D B-mode. Ultrasound Med Biol 2001; 27(6): 785-794, http://dx.doi. org/10.1016/s0301-5629(01)00351-9.

34. Milyagin V.A., Milyagina I.V., Grekova M.V. The new automated method for determining the speed of the pulse wave propagation. Funktsional'naya diagnostika 2004; 1: 33-39.

35. Jatoi N.A., Mahmud A., Bennett K., Feely J. Assessment of arterial stiffness in hypertension: comparison of oscillometric (Arteriograph), piezoelectronic (Complior) and tonometric (SphygmoCor) techniques. J Hypertens 2009; 27(11): 21862191, http://dx.doi.org/10.1097/hjh.0b013e32833057e8.

36. Lelyuk V.G., Lelyuk S.E. Ul'trazvukovaya angiologiya [Ultrasonic angiology]. Moscow; 2003; 336 p.

37. Laurent S., Katsahian S., Fassot C., Tropeano A.-I., Gautier I., Laloux B., Boutouyrie P. Aortic stiffness is an independent predictor of fatal stroke in essential hypertension. Stroke 2003; 34(5): 1203-1206, http://dx.doi.org/10.1161/01. STR.0000065428.03209.64.

38. Malshi E., Morizzo C., Florescu M., Kozakova M., Vinereanu D., Palombo C. P.054 Local arterial wave speed at carotid artery level is representative of carotido-femoral pulse wave velocity and aortic stiffness: evidence by a new echotracking approach. Artery Research 2006; 1(Suppl 1): S40, http://dx.doi.org/10.1016/s1872-9312(07)70077-7.

39. Wilkinson I.B., Prasad K., Hall I.R., Thomas A., MacCallum H., Webb D.J., Frenneaux M.P., Cockcroft J.R. Increased central pulse pressure and augmentation index in subjects with hypercholesterolemia. J Am Coll Cardiol 2002; 39(6): 1005-1011, http://dx.doi.org/10.1016/s07351097(02)01723-0.

40. Zieman S.J., Melenovsky V., Kass D.A. Mechanisms, pathophysiology, and therapy of arterial stiffness. Arterioscler Thromb Vasc Biol 2005; 25(5): 932-943, http://dx.doi. org/10.1161/01.atv.0000160548.78317.29.

41. Homma S., Hirose N., Ishida H., Ishii T., Araki G. Carotid plaque and intima-media thickness assessed by B-mode ultrasonography in subjects ranging from young adults to centenarians. Stroke 2001; 32(4): 830-501, http://dx.doi. org/10.1161/01.str.32.4.830.

42. Moiseeva N.M., Ponomarev Yu.A., Sergeeva M.V., Rogoza A.N. Evaluation of main arteries rigidity indices according to the data of bifunctional 24-hour BP and ECG monitoring with the BPLab device. Arterial'naya gipertenziya 2007; 13(1): 34-38.

43. Meinders J.M., Kornet L., Brands P.J., Hoeks A.P. Assessment of local pulse wave velocity in arteries using $2 \mathrm{D}$ distension waveforms. Ultrason Imageing 2001; 23(4): 199215, http://dx.doi.org/10.1177/016173460102300401.

44. Riley W.A., Barnes R.W., Evans G.W., Burke G.L. Ultrasonic measurement of the elastic modulus of the common carotid artery. The Atherosclerosis Risk in Communities (ARIC) Study. Stroke 1992; 23(7): 952-956, http://dx.doi. org/10.1161/01.STR.23.7.952.
45. Vriz O., Driussi C., La Carrubba S., Di Bello V., Zito C., Carerj S., Antonini-Canterin F. Comparison of sequentially measured Aloka echo-tracking one-point pulse wave velocity with SphygmoCor carotid-femoral pulse wave velocity. SAGE Open Med 2013; 1: 2050312113507563 , http://dx.doi. org/10.1177/2050312113507563.

46. Magda S.L., Ciobanu A.O., Florescu M., Vinereanu D. Comparative reproducibility of the noninvasive ultrasound methods for the assessment of vascular function. Heart Vessels 2013; 28(2): 143-150, http://dx.doi.org/10.1007/ s00380-011-0225-2.

47. Arterial elasticity in healthy Chinese. Chinese Journal of Ultrasonography 2008; 17(7): 571-575.

48. Zhang P., Guo R., Li Z., Xiao D., Ma L., Huang P., Wang C. Effect of smoking on common carotid artery wall elasticity evaluated by echo tracking technique. Ultrasound Med Biol 2014; 40(3): 643-649, http://dx.doi.org/10.1016/j. ultrasmedbio.2013.10.009.

49. Ferraioli G., Tinelli C., Maggi P., Gervasoni C., Grima P., Viskovic K., Carerj S., Filice G., Filice C. Arterial stiffness evaluation in HIV-infected: a multicenter matched control study. AJR Am J Roentgenol 2011; 197(5): 1258-1262, http://www. ajronline.org/doi/abs/10.2214/AJR.11.6712.

50. Sudano I., Spieker L.E., Noll G., Corti R., Weber R. Cardiovascular disease in HIV infection. Am Heart J 2006; 151(6): 1147-1155, http://dx.doi.org/10.1016/j. ahj.2005.07.030.

51. Yang S., Wang D., Zhang H., He W., Chen B. Echo-tracking technology assessment of carotid artery stiffness in patients with coronary slow flow. Ultrasound Med Biol 2015; 41(1): 72-76, http://dx.doi.org/10.1016/j. ultrasmedbio.2014.08.015.

52. Sutton-Tyrrell K., Najjar S.S., Boudreau R.M., Venkitachalam L., Kupelian V., Simonsick E.M., Havlik R., Lakatta E.G., Spurgeon H., Kritchevsky S., Pahor M., Bauer D., Newman A.; for the Health ABC Study. Elevated aortic pulse wave velocity, a marker of arterial stiffness, predicts cardiovascular events in well-functioning older adults. Circulation 2005; 111(25): 3384-3390, http://dx.doi. org/10.1161/circulationaha.104.483628.

53. Arnett D.K., Chambless L.E., Kim H., Evans G.W., Riley W. Variability in ultrasonic measurements of arterial stiffness in the atherosclerosis risk in communities study. Ultrasound Med Biol 1999; 25(2): 175-180, http://dx.doi. org/10.1016/s0301-5629(98)00165-3.

54. Hollander M., Hak A.E., Koudstaal P.J., Bots M.L., Grobbee D.E., Hofman A., Witteman J.C., Breteler M.M. Comparison between measures of atherosclerosis and risk of stroke. The Rotterdam Study. Stroke 2003; 34(10): 2367-2372, http://dx.doi.org/10.1161/01.str.0000091393.32060.0e.

55. Dijk J.M., Algra A., van der Graaf Y., Grobbee D.E., Bots M.L. Carotid stiffness and the risk of new vascular events in patients with manifest cardiovascular disease. The SMART study. Eur Heart J 2005; 26(12): 1213-1220, http://dx.doi. org/10.1093/eurheartj/ehi254.

56. Henry R.M., Kostense P.J., Spijkerman A.M., Dekker J.M., Nijpels G., Heine R.J., Kamp O., Westerhof N., Bouter L.M., Stehouwer C.D. Arterial stiffness increases with deteriorating glucose tolerance status: the Hoorn Study. Circulation 2003; 107(16): 2089-2095, http://dx.doi. org/10.1161/01.CIR.0000065222.34933.FC.

57. Schram M.T., Schalkwijk C.G., Bootsma A.H., Fuller J.H., Chaturvedi N., Stehouwer C.D.; on behalf of 
the EURODIAB Prospective Complications Study Group. Advanced glycation end products are associated with pulse pressure in type 1 diabetes. The EURODIAB Prospective Complications Study. Hypertension 2005; 46(1): 232-237, http://dx.doi.org/10.1161/01.HYP.0000164574.60279.ba.

58. Gurfinkel Yu.I., Katse N.V., Parfenova L.M., Ivanova I.Yu., Orlov V.A. Pulse wave velocity and endothelial function comparison in healthy people and cardiovascular patients. Rossiyskiy kardiologicheskiy zhurnal 2009; 2(76): 38-43.

59. Ilyukhin O.V., Lopatin Yu.M. Pulse wave velocity and elastic features of magistral arteries: factors, affecting their mechanical properties and possibilities of their diagnostic evaluation. Vestnik Volgogradskogo gosudarstvennogo meditsinskogo universiteta 2006; 1(17): 3-9.

60. Milyagin V.A., Filichkin D.E., Shpynev K.V., Shpyneva Z.M., Milyagina I.V. Contour analysis of central and peripheral pulse wave in healthy people and in hypertensive patients. Arterial'naya gipertenziya 2009; 15(1): 78-85.

61. London G.M., Marchais S.J., Guerin A.P., Metivier F., Adda $\mathrm{H}$. Arterial structure and function in end-stage renal failure. Nephrol Dial Transplant 2002; 17(10): 1713-1724, http://dx.doi.org/10.1093/ndt/17.10.1713.

62. Tozawa M., Iseki K., Iseki C., Takishita S. Pulse pressure and risk of total mortality and cardiovascular events in patients on chronic hemodialysis. Kid Int 2002; 61(2): 717726, http://dx.doi.org/10.1046/j.1523-1755.2002.00173.x.

63. Seyrek N., Balal M., Karayaylali I., Paydaş S., Aikimbaev K., Cetiner S., Seydaoglu G. Which parameter is more influential on the development of arteriosclerosis in hemodialysis patients? Renal Fail 2003; 25(6): 1011-1018, http://dx.doi.org/10.1081/jdi-120026036.

64. Mourad J.J., Pannier B., Blacher J., Rudnichi A., Benetos A., London G.M., Safar M.E. Creatinine clearance, pulse wave velocity, carotid compliance and essential hypertension. Kidney Int 2001; 59(5): 1834-1841, http://dx.doi. org/10.1046/j.1523-1755.2001.0590051834.x.

65. Covic A., Gusbeth-Tatomir P., Goldsmith D.J.A. Arterial stiffness in renal patient: an update. Am J Kidney Dis 2005; 45(6): 965-977, http://dx.doi.org/10.1053/j.ajkd.2005.02.026.

66. Barenbrock M., Kosch M., Jöster E., Kisters K., Rahn K.H., Hausberg M. Reduced arterial distensibility is a predictor of cardiovascular disease in patients after renal transplantation. J Hypertens 2002; 20(1): 79-84, http://dx.doi. org/10.1097/00004872-200201000-00012.

67. Pannier B., Guérin A.P., Marchais S.J., Safar M.E., London G.M. Stiffness of capacitive and conduit arteries: prognostic significance for end-stage renal disease patients. Hypertension 2005; 45(4): 592-596, http://dx.doi. org/10.1161/01.hyp.0000159190.71253.c3.

68. Niki K., Sugawara M., Chang D., Harada A., Okada T., Sakai R., Uchida K., Tanaka R., Mumford C.E. A new noninvasive measurement system for wave intensity: evaluation of carotid arterial wave intensity and reproducibility. Heart Vessels 2002; 17(1): 12-21, http://dx.doi.org/10.1007/ s003800200037.

69. Yusuf S., Hawken S., Ounpuu S., Dans T., Avezum A., Lanas F., McQueen M., Budaj A., Pais P., Varigos J., Lisheng L.; on behalf of the INTERHEART Study Investigators. Effect of potentially modifiable risk factors associated with myocardial infarction in 52 countries (the INTERHEART study): case-control study. Lancet 2004; 364(9838): 937-952, http:// dx.doi.org/10.1016/s0140-6736(04)17018-9.
70. ESC/EAS Guidelines for the management of dyslipidaemias. Ateroskleroz i dislipidemii 2011; 4: 5-7.

71. Kukharchuk V.V. Arterial'naya gipertoniya, narusheniya lipidnogo obmena i ateroskleroz. $\mathrm{V}$ kn.: Rukovodstvo po arterial'noy gipertonii [Arterial hypertension, lipid disorders and atherosclerosis. In: Guide to an arterial hypertension]. Pod red. Chazova E.I., Chazovoy I.E. [Chazov E.I., Chazova I.E. (editors)]. Moscow: Media Medika; 2005; p. 289-299.

72. Brunner H., Cockcroft J.R., Deanfield J., Donald A., Ferrannini E., Halcox J., Kiowski W., Lüscher T.F., Mancia G., Natali A., Oliver J.J., Pessina A.C., Rizzoni D., Rossi G.P., Salvetti A., Spieker L.E., Taddei S., Webb D.J. Endothelial function and dysfunction. Part II: Association with cardiovascular risk factors and diseases. A statement by the Working Group on Endothelins and Endothelial Factors of the European Society of Hypertension. J Hypertens 2005; 23(2): 233-246, http://dx.doi. org/10.1097/00004872-200502000-00001.

73. Waddell T.K., Dart A.M., Medley T.L., Cameron J.D., Kingwell B.A. Carotid pressure is a better predictor of coronary artery disease severity than brachial pressure. Hypertension 2001; 38(4): 927-931, http://dx.doi.org/10.1161/ hy1001.096107.

74. DeLoach S.S., Townsend R.R. Vascular stiffness: its measurements and significance for epidemiologic and outcome studies. Clin J Am Soc Nephrol 2008; 3(1): 184-192, http:// dx.doi.org/10.2215/cjn.03340807.

75. Paini A., Boutouyrie P., Calvet D., Tropeano A.-I., Laloux B., Laurent S. Carotid and aortic stiffness: determinants of discrepancies. Hypertension 2006; 47(3): 371-376, http:// dx.doi.org/10.1161/01.hyp.0000202052.25238.68.

76. Hughes A.D., Sinclair A.M., Geroulakos G., Mayet J., Mackay J., Shahi M., Thom S., Nicolaides A., Sever P.S. Structural changes in the heart and carotid arteries associated with hypertension in humans. J Human Hypertens 1993; 7(4): 395-397.

77. Jiang B., Liu B., McNeill K.L., Chowienczyk P.J. Measurement of pulse wave velocity using pulse wave Doppler ultrasound: comparison with arterial tonometry. Ultrasound Med Biol 2008; 34(3): 509-512, http://dx.doi.org/10.1016/j. ultrasmedbio.2007.09.008.

78. Simons P.C., Algra A., Bots M.L., Grobbee D.E., van der Graaf Y. Common carotid intima-media thickness and arterial stiffness. Indicators of cardiovascular risk in high-risk patients. The SMART Study (Second Manifestations of ARTerial disease). Circulation 1999; 100(9): 951-957, http://dx.doi. org/10.1161/01.cir.100.9.951.

79. Boutouyrie P., Pannier B. Measurement of arterial stiffness. In: Central aortic blood pressure. Laurent S., Cockroft J. (editors). France; 2008; p. 41-47.

80. Kelly R., Hayward C., Ganis J., Daley J., Avolio A., O'Rourke M. Noninvasive registration of the arterial pressure pulse waveform using high-fidelity applanation tonometry. J Vasc Med Biol 1989; 1: 142-149.

81. Ahuja K.D., Robertson I.K., Ball M.J. Acute effects of food on postprandial blood pressure and measures of arterial stiffness in healthy humans. Am J Clin Nutr 2009; 90(2): 298303, http://dx.doi.org/10.3945/ajcn.2009.27771.

82. Cheng K.S., Baker C.R., Hamilton G., Hoeks A.P., Seifalian A.M. Arterial elastic properties and cardiovascular risk/event. Eur J Vasc Endovasc Surg 2002; 24(5): 383-397, http://dx.doi.org/10.1053/ejvs.2002.1756.

83. Gamble G., Zorn J., Sanders G., MacMahon S., Sharpe N. Estimation of arterial stiffness, compliance, and 
distensibility from M-mode ultrasound measurements of the common carotid artery. Stroke 1994; 25(1): 11-16, http:// dx.doi.org/10.1161/01.str.25.1.11.

84. Beaussier H., Masson I., Collin C., Bozec E., Laloux B., Calvet D., Zidi M., Boutouyrie P., Laurent S. Carotid plaque, arterial stiffness gradient, and remodeling in hypertension. Hypertension 2008; 52(4): 729-736, http://dx.doi.org/10.1161/ hypertensionaha.108.115972.

85. Beaussier H., Naggara O., Calvet D., Joannides R., Guegan-Massardier E., Gerardin E., lacob M., Laloux B., Bozec E., Bellien J., Touze E., Masson I., Thuillez C., Oppenheim C., Boutouyrie P., Laurent S. Mechanical and structural characteristics of carotid plaques by combined analysis with echotracking system and MR imaging. JACC Cardiovasc Imaging 2011; 4(5): 468-477, http://dx.doi. org/10.1016/j.jcmg.2011.01.017

86. Martynov A.I., Sinitsin V.E., Ternovoy S.K., Pustovitova T.S., Ostroumova O.D., Sharkova N.E., Gedgafova S.Yu. Changes of distensibility of the aorta in elderly patients during long-term therapy with various classes of hypotensive drugs. Kardiologiya 2002; 42(5): 19-22.

87. Blacher J., Pannier B., Guerin A.P., Marchais S.J., Safar M.E., London G.M. Third workshop on structure and function of large arteries: part III. Carotid arterial stiffness as a predictor of cardiovascular and all-cause mortality in end-stage renal disease. Hypertension 1998; 32(3): 570-574, http:// dx.doi.org/10.1161/01.hyp.32.3.570.

88. Boutouyrie P., Laurent S., Benetos A., Girerd X.J., Hoeks A.P.G., Safar M.E. Opposing effects of ageing on distal and proximal large arteries in hypertensives. $J$ Hypertens Suppl 1992; 10(6): S87-S91, http://dx.doi.org/10.1097/00004872$199208001-00023$.

89. Williams B., Lacy P.S., Thom S.M., Cruickshank K., Stanton A., Collier D., Hughes A.D., Thurston H., O'Rourke M.; CAFE Investigators; Anglo-Scandinavian Cardiac Outcomes Trial Investigators; CAFE Steering Committee and Writing Committee. Differential impact of blood pressure-lowering drugs on central aortic pressure and clinical outcomes: principal results of the Conduit Artery Function Evaluation (CAFE) study. Circulation 2006; 113(9): 1213-1225, http:// dx.doi.org/10.1161/CIRCULATIONAHA.105.595496.

90. Cruickshank K., Riste L., Anderson S.G., Wright J.S., Dunn G., Gosling R.G. Aortic pulse-wave velocity and its relationship to mortality in diabetes and glucose intolerance: an integrated index of vascular function? Circulation 2002; 106(16): 2085-2090, http://dx.doi.org/10.1161/01. cir.0000033824.02722.f7.

91. Millasseau C., Kelly R., Ritter J., Chowienczyk P.J. The vascular impact of aging and vasoactive drugs: comparison of two digital volume pulse measurement. Am J Hypertens 2003; 16(6): 467-472, http://dx.doi.org/10.1016/s08957061(03)00569-7.

92. Lopatin Yu.M., Ilyukhin O.V., Ilyukhina M.V., Ivanenko V.V. Arterial elasticity and pulse wave velocity in patients with chronic heart failure of various etiologies. Zhurnal serdechnaya nedostatochnost' 2004; 5(4): 130-131.

93. Tripoten' M.I., Balakhonova T.V., Rogoza A.N. Comparative assessment of M-mode and Echo-Tracking technology in determination of common carotid arteries stiffness. Ul'trazvukovaya i funktsional'naya diagnostika 2011; 6: $50-56$.

94. Milyagina I.V., Milyagin V.A., Pozdnyakov Yu.M., Leksina Yu.N., Kopteva V.V. Cardio-ankle vascular index a new cardiovascular risk predictor. Kardiovaskulyarnaya terapiya i profilaktika 2008; 7(7): 22-26.

95. Matrosova I.B., Melnikova E.A., Oleynikov V.E. Effects of olmesartan on local and regional rigidity of arteries in ischemic heart disease. Kardiovaskulyarnaya terapiya $i$ profilaktika 2014; 13(3): 41-46.

96. Wilkinson I.B. The pharmacodynamics of central blood pressure. In: Central aortic blood pressure. Laurent S., Cockroft J. (editors). France; 2008; p. 69-74.

97. Chow B., Rabkin S.W. Brachial-ankle pulse wave velocity is the only index of arterial stiffness that correlates with a mitral valve indices of diastolic dysfunction, but no index correlates with left atrial size. Cardiol Res Pract 2013; 2013: 986847, http://dx.doi.org/10.1155/2013/986847.

98. Kampus P., Serg M., Kals J., Zagura M., Muda P., Karu K., Zilmer M., Eha J. Differential effects of nebivolol and metoprolol on central aortic pressure and left ventricular wall thickness. Hypertension 2011; 57(6): 1122-1128, http://dx.doi. org/10.1161/hypertensionaha.110.155507.

99. Leone N., Ducimetière P., Gariépy J., Courbon D., Tzourio C., Dartigues J.-F., Ritchie K., Alpérovitch A., Amouyel P., Safar M.E., Zureik M. Distension of the carotid artery and risk of coronary events: the three-city study. Arterioscler Thromb Vasc Biol 2008; 28(7): 1392-1397, http:// dx.doi.org/10.1161/atvbaha.108.164582. 